\title{
STUDI SEJARAH DAN BUDAYA LOMBOK (TINJAUAN BUKU)
}

\author{
${ }^{1}$ Abdul Rasyad, ${ }^{1}$ Lalu Murdi \\ 1,2 Universitas Hamzanwadi \\ rasyad.iis@gmail.com, 1alumurdi@ymail.com
}

\begin{abstract}
Abstrak
Tulisan ini merupakan resensi dari buku yang berjudul "Studi Sejarah dan Budaya Lombok". Secara umum buku ini mencoba menjelaska tentang budaya masyarakat Sasak-Lombok. Masyarakat Sasak dijelaskan dalam perspektif budayanya dan menunjukkan bahwa budaya pada masyarakat Sasak masih terjaga dengan baik. Perlu menjadi catatan dalam buku ini adalah kepustakaan yang menjadi acuan. Artinya, kepustakaan yang digunakan belum begitu menunjukkan kualitas yang sesungguhnya.
\end{abstract}

Kata Kunci: Studi Sejarah, Budaya Lombok

\section{PENDAHULUAN}

Buku 'Studi Sejarah dan Budaya Lombok', ditulis oleh Sudirman dan Bahri, diterbitkan PUSAKANDA tahun 2014. Buku ini merupakan salah satu dari sekian buku yang coba menghadirkan khasanah sosial dan budaya masyarakat Sasak dalam perjalanan sejarahnya maupun sistem sosial dan budaya saat ini. Meski demikian setiap kajian yang berbeda, walaupun tidak lepas dari apa yang sudah dipaparkan dalam bukubuku sejarah tentang Lombok, buku ini tentunya memiliki kekhasan tersendiri dalam menghadirkan sejarah dan budaya masyarakat Sasak tersebut.

Aspek lainnya, yang membuat buku ini menarik untuk didiskusikan karena selain merupakan proyek kerjasama dengan BAPPEDA Lombok Timur, sekaligus bisa dikatakan salah satu buku "babon" dengan pembahasan dan jumlah halaman serta bab yang lebih banyak dari buku-buku tentang sejarah masyarakat Sasak Lombok sebelumnya. Begitu juga dengan kekhasannya, buku ini coba mengaitkan beberapa legenda masyarakat Sasak sebagai bagian dari asal-usul masyarakatnya.

Buku dengan 523 alaman ini terdapat 13 bab secara terpisah membahas sejarah dan budaya masyarakat Sasak, terutama sekali budaya yang sifatnya normatif. Bab I sampai bab IX menguraikan sejarah masyarakat Sasak sejak zaman prasejarah sampai kehidupan masyarakat pasca kemerdekaan. Berhubung sejarah yang dipaparkan lebih banyak terkait dengan kehidupan politik dan orang-orang besar, terutama ketika berbicara tentang kerajaan dan tokoh-tokoh Islam, maka tidak salah apabila dikatakan 
bahwa pendekatan sejarah yang digunakan dalam tulisan ini berkaitan erat dengan sejarah politik.

Bab X sampai bab XII menguraikan aspek sosio-kultural masyarakat Sasak seperti tata kehidupan sosial budaya; tradisi yang ada dalam masyarakat; serta seni dan permainan masyarakat. Pemetaan secara khusus ini, kemungkinan besar tidak lepas dari judul yang dibuat dan dipahami oleh penulis buku. Sebagai tambahan, dalam buku ini dicantumkan beberapa silsilah dari beberapa kerajaan yang pernah ada di Lombok seperti Datu Bayan, Kerajaan Langko, dan Kerajaan Selaparang. Silsilah-silsilah tersebut tentunya memerlukan kerjakeras untuk dapat menemukan dan menyusunnya. Sepertinya hal terakhir merupakan kelebihan tersendiri dari penulis buku ini.

Aspek lainnya, terutama yang berkaitan dengan sejarah, sepertinya buku ini lebih banyak mengkaji literatur atau buku yang sudah ditulis sebelumnya, dan masih tampak sedikit sekali merupakan kajian awal dan informasi baru yang dipaparkan. Begitu juga halnya dengan budaya yang dipaparkan, sekali lagi tidak lebih merupakan budaya normatif yang seharusnya ada dalam kehidupan masyarakat, bukan bagaimana masyarakat memfungsikan budaya yang ada dalam perjalanan waktu sampai pada kekinian.

Terlepas dari begitu baiknya buku ini untuk dapat memberikan informasi kepada pembaca mengenai sejarah dan budaya masyarakat Sasak Lombok, sebagaimana yang diungkapkan pihak penerbit ketika bertemu secara langsung dengan penulis, buku ini perlu mendapatkan sentuhan kajian ilmiah, terutama kajian sejarah yang menggunakan pendekatan ilmiah. Dengan kata lain, buku ini dalam istilahnya pihak penerbit "perlu edisi revisi yang lebih baik'.

Istilah "studi" pada awal buku ini seperti dijelaskan oleh pihak penerbit tidak lepas dari isi buku yang lebih cendrung mengungkapkan data-data lama, dan sangat kurang akan evidensi-evidensi baru. Begitu juga dengan priodesasi yang dibangun oleh penulis buku ini perlu mendapatkan perhatian dan analisa yang cermat. Inilah yang coba kami diskusikan dalam tulisan ini.

\section{KAJIAN SISTEMATIKA PENULISAN}

Salah satu ciri khas ilmu sejarah yaitu menekankan pada aspek diakronis dan memanjang dalam waktu (Kuntowijoyo, 2005: 108). Artinya bahwa yang menjadi pokok persoalan dari studi sejarah, meminjam istilahnya Taufik Abdullah dan Abdurrchman Surjomihardjo (1983) batasan "dari dan sampai bila" harus terpenuhi. 
Dengan demikian, waktu menjadi sangat penting dalam ilmu sejarah. Ini juga yang membedakan ilmu sejarah dengan ilmu sosial lainnya yang bersifat nomotetis (melebar dalam ruang).

Setiap penulisan sejarah karenanya harus membuat priodesasi yang jelas dalam perubahan waktu. Sepertinya tidak perlu diberikan contoh seperti apa para penulis sejarah membuat pembabakan waktu, buku 'Sejarah Nasional Indonesia I sampai VI' yang memang ditulis oleh para ahli sejarah senior Indonesia dengan pendekatan metodologi sejarah yang ilmiah bisa menjadi salah satu contoh dari sekian banyak contoh lainnya. Begitu juga dengan bagaimana para penulis sejarah Indonesia sebelumnya seperti H.J. de Graf dalam "Geschiedenis van Indonesia", Prof. Moh. Yamin dalam "6000 Tahun Sang Merah Putih", Tan Malaka dalam "Massa Actia”, dan lain-lain, bagaimana mereka membuat priodesasi sejarah dapat dibaca dalam bukunya Rustam E. Tamburaka (2002).

Buku-buku sejarah yang sifatnya lokal, seperti "Sejarah Daerah Nusa Tenggara Barat" oleh Lalu Wacana, dkk (1977), dan "Pulau Lombok dalam Sejarah Ditinjau dari Apek Budaya" oleh Lalu Lukman (2008), tidak jauh berbeda dengan buku-buku sejarah yang bersekala nasional di atas, karena memang terutama pada buku yang disebut pertama memiliki tim penyempurna naskah, yang mana mereka merupakan sejarawansejarawan Indonesia seperti Abdurracman Surjomihardjo, Anhar Gonggong, A. B. Lapian, dan lain-lain. Buku-buku ini seperti biasanya penulisan buku sejarah, membangun priodesasi berdasarkan urutan waktu secara kronologis.

Tujuan kami menguraikan contoh pembabakan waktu yang biasanya dibangun oleh para penulis sejarah di atas, tidak lain untuk membandingkannya dengan buku yang kalau dihitung halamannya merupakan buku sejarah yang istimewa. Selain itu, dengan membandingkannya dengan buku-buku lain maka kami memiliki dasar dan referensi untuk mendialogkan teks dengan teks.

Membaca bab II 'zaman prasejarah suku Sasak-Lombok, dan bab III 'Suku Sasak Lombok memasuki zaman kuno' pada buku "Studi Sejarah dan Budaya Lombok" telah menggambarkan perkembangan sejarah dalam perkembangan bab. Dilanjutkan dengan bab IV 'masuk dan berkembangnya Islam di Pulau Lombok'; bab V 'Biografi singkat Tokoh Islam Sasak-Lombok, yang sepertinya mendahului bab selanjutnya yang menguraikan tentang 'kerajaan-kerajaan Sasak Lombok'.

Buku "Studi Sejarah dan Budaya Lombok", yang secara khusus dapat dipahami dari judulnya mengungkap sejarah masyarakat Sasak, pada dasarnya coba menguraikan 
perkembangan sejarah dalam perkembangan yang ada. Namun hal ini kebanyakan dilakukan berdasarkan tema dari masing-masing bab yang dibuat. Artinya bahwa penulis buku dalam beberapa bab tidak memperhatikan urutan priodesasi berdasarkan perubahan waktu dalam sejarah masyarakat Sasak. Membaca sejarah masyarakat Sasak-Lombok, semua orang akan mengatakan dan menyadari bahwa seharusnya yang didahulukan adalah Kerajaan Sasak-Lombok, daripada membicarakan biografi tokohtokoh Islam yang keberadaannya tidak lebih dari abad ke-18, 19, bahkan abad ke-20 seperti yang diuraikan dalam buku tersebut.

Berdasarkan uraian tersebut, memang sepertinya penulis buku ini dan pihak yang member proyek dalam hal ini BAPPEDA Lotim tidak bertujuan untuk menulis sejarah Lombok yang menggunakan sistematika sejarah yang sistematis dengan penulisan pembabakan waktu yang kronologis seperti pada umumnya buku sejarah lainnya. Adapun terkait dengan aspek budaya yang dibahas secara terpisah dalam buku ini sepertinya berangkat dari judul, yaitu 'sejarah dan budaya', buka 'sejarah budaya', sehingga barangkali inilah yang membuat penulis buku ini secara terpisah membuatkan bab-bab khusus untuk menguraikan sejarah, selanjutnya menulis tentang kebudayaan masyarakat Sasak Lombok.

\section{KAJIAN ISI BUKU}

Terlepas dari perbedaan sistematika pembabakan sejarah yang dibangun, penulis buku "Studi Sejarah dan Budaya Lombok" telah memberikan kontribusi yang penting untuk terus memperkenalkan sejarah dan budaya masyarakat Sasak yang memang masih memerlukan sentuhan untuk diperkenalkan pada masyarakat Sasak dan Indonesia pada khususnya, dan tentunya dunia Internasional pada umumnya. Keberadaan pulau Lombok yang menjadi bagian dari destinasi pariwisata terpenting di Indonesia, dengan keberadaan tulisan-tulisan semacam ini tentunya sangat relevan.

Membaca isi buku ini, secara keseluruhan mulai dari sejarah dan budaya yang menjadi kajiannya tidak jauh berbeda dengan beberapa tulisan lain sebelumnya, karenanya wajar jika pihak penerbit sendiri menjelaskan bahwa buku ini lebih merupakan kajian perbandingan teks yang sudah ada daripada kajian mendalam yang sifatnya baru. Dengan kata lain, buku ini secara garis besar menyajikan sejarah dan sosial budaya masyarakat Sasak berdasarkan kajian kepustakaan.

Adalah sangat wajar jika dikatakan demikian, uraian tentang sejarah masyarakat Sasak Lombok, mulai dari istilah Sasak, asal usul suku Sasak, dan sebagainya sampai 
pada sejarah masyarakat Sasak setelah kemerdekaan, informasi yang disuguhkan tidak jauh berbeda dengan beberapa buku sebelumnya seperti "Sejarah Daerah Nusa Tenggara Barat" yang merupakan proyek proyek penelitian dan pencatatan kebudayaan daerah oleh Depdikbud, diterbitkan 1987, dengan ketua peneliti Lalu Wacana. "Pulau Lombok dalam Sejarah ditinjau dari Aspek Budaya", dan lain sebagainya.

Kekhasan, disamping keberadaan buku ini lebih merupakan kajian kepustakaan, adalah kajiannya tentang legenda-legenda masyarakat yang coba dianalisa sebagai bagian dari sejarah masyaraka Sasak sendiri. Tentunya hal tersebut menjadi bagian dari perbedaan buku ini dengan buku-buku yang lain. Selain itu, yang cukup menarik adalah usaha dari kedua penulis untuk menemukan dan menyusun silsilah raja dari beberapa kerajaan Sasak Lombok.

Salah satu yang menarik adalah ketika membicarakan tentang asal usul nenek moyang suku Sasak, penulis coba menguraikan tingkat perkembangannya berdasarkan asal usul orang Sasak di Pulau Lombok, yang diambilnya dari Legenda Doyan Nada dan Legenda Gunung Pujut. Penulis sepertinya meyakini sekali bahwa legenda-legenda tersebut sesungguhnya merupakan bagian dari sejarah masyarakat Sasak yang sebenarnya. Dengan kata lain, bukan hanya sebagai sebuah cerita hayalan dan mitos, namun juga sebuah kebenaran sejarah yang terekam dalam oral tradition masyarakat Sasak.

Tidak ada uraian lebih lanjut mengenai legenda yang coba dimasukkan sebagai bagian penting dari perkembangan masyarakat Sasak, atau proses sinkronisasi antara legenda-legenda yang dimasukkan dengan data-data arkeologis yang kemudian dibahas dalam buku ini. Halaman 6 sampai 7 dari buku ini secara langsung mengupas dua hal yang berbeda tanpa adanya proses analisa yang mendalam, yaitu menghadirkan legenda kemudian memberikan ganmabaran temuan arkeologis yang memang tidak memiliki koneksi antara keduanya.

Ada kemungkinan besar yang diinginkan disampaikan oleh penulis yang secara langsung kami dengarkan dari pemaparan kedua penulis buku dalam perbincangan di lembaga penerbit PUSAKANDA, bahwa mereka ingin menemukan titik temu antara temuan arkeologis yang sifatnya ilmiah dan legenda yang tersebar dalam masyarakat Sasak, dengan keyakinan bahwa tidak mungkin cerita tersebut akan tersebar luas sampai saat ini jika tidak pernah terjadi pada masa lalu.

Pandangan demikian ada benarnya juga, namun memperhatikan legenda-legenda yang ada, tidak ubahnya semacam cerita yang berkembang dari kerajaan-kerajaan yang 
pernah ada sebagai proses yang lebih dikenal sekarang ini sebagai "legitimasi". Perhatikan saja misalnya dari Legenda Doyan Nada dan Legenda Gunung Pujut yang diuraikan dalam buku ini. Dalam Legenda Doyan Nada misalnya, diceritakan bahwa Datu Tuan mempunyai dua orang putra yaitu Raden Nune Putra Janjak dan Dewi Anjani. Salah seorang bangsawan terkenal yang merupakan pengikut Dewi Anjani bernama Penghulu Alim, dialah yang melahirkan keturunan yang katanya kelak mendirikan kerajaan-kerajaan di berbagai tempat di pulau Lombok seperti Selaparang, Pejanggik, Langko dan Bayan.

Sedangkan dari legenda Gunung Pujut, dijelaskan sebagai berikut:

"Pangeran dari Majapahit mengembara kea rah Timur. Setelah kawin dengan Putri Kerajaan Kelungkung (Bali), rombongan menyebrang ke bagian timur yaitu Pulau Lombok dan membangun negeri baru di sekitar Gunung Pujut. Legenda tersebut menjelaskan bahwa nenek moyang Suku Sasak khususnya Lombok Selatanberasal dari Majapahit yang bercampur darah Kelungkung. Hal ini merupakan alasan sehingga orang-orang Bali berdatangan lagi pada awal perkembangan Kerajaan Pejanggik (2014: 7).

Seperti dijelaskan sebelumnya bahwa mencermati kedua legenda di atas, adalah wajar apabila dikatakan bahwa sepertinya hal tersebut lebih kelihatan sebagai proses legitimasi. Adalah sangat tidak mungkin, jika dibandingkan dengan data-data arkeologis yang ada dan disajikan juga dalam buku tersebut jika mengatakan berdasarkan legenda yang ada sebagai asal-usul suku Sasak, kecuali mungkin keberadaan dari kerajaankerajaan. Karena perkembangan kerajaan yang pernah ada di Lombok tidak bisa lepas dari keberadaan kerajaan-kerajaan lainnya baik yang ada di Jawa maupun yang ada di Bali. Adapun masyarakat Sasak pada umumnya sudah ada sebelum kerajaan-kerajaan tersebut muncul.

Aspek lainnya yang menarik perhatian dari buku ini seperti diuraikan sebelumnya adalah usaha dari penulis untuk menemukan, menyusun, kemudian menyajikan silsilah beberapa kerajaan Lombok seperti silsilah Datu Bayan, Silsilah Kerajaan Langko, dan silsilah Kerajaan Selaparang. Diakui oleh penilis, hal ini cukup sulit, rumit dan menyita waktu penelitian. Sepertinya menjadi salah satu kredit point bagi penulis buku ini. Karena tidak banyak buku-buku sejarah lainnya yang mengungkapkan hal tersebut.

\section{KESIMPULAN}


Wacana dialog pradaban yang banyak didengungkan, meminjam istilahnya Azyumardi Azra (2007), harus dalam lingkup yang "multilateral", memerlukan pemahaman yang kuat dan mendalam akan aspek lokalitas yang dimiliki. Karena jika ingin memperkenalkan, apalagi mendialogkan dengan peradaban yang sifatnya global, kearifan lokal memiliki arti yang mendalam. Buku "Studi Sejarah dan Budaya Lombok", merupakan salah satu yang mencoba menguraikan kebutuhan akan pemahaman sejarah dan budaya lokal yang dapat diperkenalkan bukan hanya pada aspek lokal, dan nasional. Keberadaannya sebagai salah satu dari lima destinasi terpenting di Indonesia menyebabkan keberadaan sejarah, dan sosial budayanya menjadi vital untuk dipublikasikan dalam ruang global.

\section{DAFTAR PUSTAKA}

Abdullah, T. dan Abdurrahman, S. (Editor). 1983. Ilmu Sejarah dan Historiografi. Arah dan Perspektif. Jakarta: Gramedia.

Azra, Azyumardi. 2007. Jejak-Jejak Jaringan Kaum Muslim dari Australia hingga Timur Tengah. Jakarta: Hikmah.

Kuntowijoyo. 2005. Pengantar Ilmu Sejarah. Yogyakarta: Bentang.

Lukman, Lalu. 2008. Pulau Lombok dalam Sejarah Ditinjau dari Aspek Budaya. TT: $\mathrm{TP}$.

Lukman, Lalu. dkk. 1978. Sejarah Daerah Nusa Tenggara Barat. Jakarta: Proyek Penelitian dan Pencatatan Kebudayaan Daerah-Depdikbud.

Poesponegoro, M. D. dan Notosusanto, Nugroho. 1993. Sejarah Nasional Indonesia Jilid I-VI. Jakarta: Depdikbud-Balai Pustaka.

Sudirman dan Bahri. 2014. Studi Sejarah dan Budaya Lombok. Selong: PUSAKANDA. Tamburaka, Rustam. 2002. Pengantar Ilmu Sejarah, Teori Filsafat Sejarah, Sejarah Filsafat dan IPTEK. Jakarta: Rineka Cipta. 